\title{
Disclosure of Risk Factors on Prospectus and Initial Public Offerings (IPO) Performance: Evidence from Indonesia
}

\author{
Randy Kuswanto \\ Accounting Program, Wiyatamandala School of Business, Indonesia \\ email:randykuswanto123@gmail.com
}

DOI: https://doi.org/10.24843/JIAB.2020.v15.i01.p02

\begin{tabular}{l}
$\begin{array}{l}\text { Jurnal Ilmiah Akuntansi } \\
\text { dan Bisnis } \\
\text { (JIAB) }\end{array}$ \\
\hline Volume 15 \\
Issue 15 \\
January 2020 \\
Page 15 - 22 \\
p-ISSN 2302-514X \\
e-ISSN 2303-1018 \\
\hline ARTICLE INFORMATION: \\
\hline Received: \\
14 May 2019 \\
Revised: \\
07 December 2019 \\
Accepted: \\
19 December 2019 \\
\hline
\end{tabular}

\begin{abstract}
The purpose of this study is to investigate how risk information disclosed in prospectus influences the initial returns of initial public offerings (IPOs) in Indonesia. This study collected 62 sample IPOs offered in the Indonesian Stock Exchange from 2017-2018. Ordinary least squares was performed to test the association between risk disclosure and initial returns. Results indicate that prospectus provides risk information associated with initial returns. Both qualitative and quantitative dimensions have a significant negative impact on the initial returns. It can be concluded that risk information has an important role in the underpricing phenomenon. The study has extended the available literature by investigating risk disclosure from a dual perspective. More over, qualitative and quantitative assessments both have a direct impact on the initial returns and must be considered in investment decision making.
\end{abstract}

Keywords: Risk, IPO, underpricing, initial returns.

\section{INTRODUCTION}

There are fundamental consideration when investing in particular asset; return and risk. Both elements have strong correlation often indicated by the classic statement "high risk, high return" (Jogiyanto (2017). One type of investment that empirically able to provide high returns is stock in an Initial Public Offering (IPO). Based on (Ozdemir \& Kizildag, 2017). The explanation of these phenomenon are caused by many factors; asymmetry information (Chhabra, et al., 2017), governance (Auliya \& Januarti, 2015; Gunawan \& Darmadi, 2013), information disclosure (Murugesu \& Santhapparaj, 2010; Wasiuzzaman, et al., 2018) and other relevant factors.

Basically, risk is inherent to many form of investments. If companies want to conduct an IPO, they needto disclose risk-related information to their potential investors. This disclosure is usually set forth in the prospectus. Prospectus is one of the required document that must be issued by companies which want to conduct an IPO. Prospectus is the main source of fundamental information for investor.
Prospectus also provides various relevant company information such as the use of IPO fund, debt statement, financial summary, history of company, underwriter, and risk faced by investor. The axiomatic expression in the previous paragraph shows there is an essential relationship between corporate return and risk. Thus, the analysis of risk disclosures in the prospectus could present new contributions to underpricing studies, especially in Indonesia. The lack of research related to the disclosure of risk factors in prospectuses in Indonesia provides an opportunity for this study to add empirical evidence that can expand the literature on corporate disclosure and the phenomenon of underpricing.

As the main source of information, prospectus contains a variety of the company's latest operative and situative information. In the context of regulations in Indonesia, contents and forms of prospectus are regulated in Peraturan Otoritas Jasa Keuangan (OJK) Nomor 8/POJK.04/2017 concerning The Form and Content of Brief Prospectus and Prospectus in the Framework of Initial Public Offering. There are four risk classifications regulated 
by OJK; major risk, business risk, general risk, and investor risk. The major risks can be sourced internally and externally which can significantly affect the company's business sustainability. The risks disclosed tend to be in a qualitative format the description of sentences/statements which (could) be formal and uniform in nature. Formality refer to information are required by the regulator so that the company can only disclose risks inherent in the company's operations which conceptually only expliciting the implicit things. Second, uniformity means each company is attached to the exact same type of risk information, even in companies with different sectors (usually investment risk). Risk analysis is not enough to support an optimal research model if only based on the disclosure of qualitative risk factors.

Wasiuzzaman et al. (2018) analyze risk qualitatively by codifying the sentences expressed in the prospectus as a proxy for the disclosure of the risk. They found that the disclosure of risk factors influenced the initial return. With different model, Murugesu and Santhapparaj (2010) analyze risk quantitatively by using 15 proxies in ratio and dummy variables to measure the effect on initial return. these studies show that risk, both qualitatively and quantitatively, affects the initial return and be the part of the underpricing phenomenon. These findings are interesting and reaffirm the associative relationship between risk and return. Risk, regardless its form, is the main substance for investor in investmen decision making. Another contribution offered by this study is to combine qualitative and quantitative risk measure in relation to initial return.

From the perspective of stakeholders, the practice of corporate risk disclosure must relate to the effectiveness of risk management and control systems to increase shareholder value (Murugesu \& Santhapparaj, 2010). This affects the company's information disclosure strategy. To reduce the deviation of information asymmetry, companies need to disclose effective information. Although IPO shares tend to provide capital gains in the short term (Colak, 2012), companies have to consider the long term effect. The risks exist in company's operations and conditions and it is significant as long as the company is established. As a speculative instrument, IPO company shares are indeed potential but investors still need to think substantially. This research presents short-term coverage related to the relationship of risk and corporate stock returns. Indirectly, this scope also becomes a limitation in this study.
According to regulations in Indonesia, the prospectus format requires companies to display primary information on the front page of the prospectus. This information written for information such as important dates related to listing of shares, number and percentage of shares issued, offering price, underwriter and the company's main risk information. This information attribute has been regulated by OJK. Several studies had examined this attribute to understand IPO stock performance patterns (Brobert, 2016; Chen \& Wang, 2016; Colak, 2012; Wasiuzzaman et al., 2018). In addition to the information presented on the prospectus front page, information in the prospectus is also often used as a key variable in various studies. For example, information related to the characteristics of the board of directors to the phenomenon of underpricing $(\mathrm{Xu}$, Wang, \& Long, 2017). Other information is intellectual capital information that is written in the prospectus (Gomez-Bezares, et al., 2015). In fact, there is study that examine audit quality on the sustainability of IPO companies (Jain, 2005).

Studies on IPO performance and underpricing that occur in various countries have often been conducted. However, only a few explored the characteristics of risk disclosure disclosed by IPO companies in prospectuses, especially in Indonesia. Risks are generally viewed as a negative item because they contain information that is potentially unfavorable to the company. The higher the risk, the lower the stock price will be. When risk have to be disclosed, a critical question arises, how is risk disclosure able to add value to the company? The theoretical relationship between risk and firm value needs to be explained in another direction. Risk needs to be seen as an ability that can reduce the cost of capital by reducing investor uncertainty (Murugesu \& Santhapparaj, 2010). Thus, risk is not always negatively related to firm value. Informative and adequate risk disclosures can improve investor perceptions and benefit all stakeholders.

Kim and Yasuda (2017) dichotomize two types of risk that a company have-called narrative risk and stock risk. Narrative risk is the risk revealed by the company in the management discussion and analysis section of the annual report. Meanwhile, stock risk is measured using a daily deviation of stock return for one year. The results of the study indicate that narrative risk disclosure can reduce the cost of capital of a company because it has a negative impact on the risk of company stock in Japan. This research supports the previous argument that risk disclosure 
can reduce information asymmetry which can reduce investor uncertainty.

Over the past decade, research on the topic of risk disclosure has been carried out frequently (Ameer \& Othman, 2009; Cordazzo et al., 2017; Craig et al, 2011; Shukor et al., 2015). However, only few research linking the topic to IPO companies. The role of empirical risk disclosure research is rarely examined but the role of risk is quite significant in the reporting process because capital market regulators require risk disclosure on the front page of a company's prospectus. This phenomenon indicates that risk disclosure tends to have a low value relevance. It can occur because the phenomenon of underpricing suggests that the risk aspects of IPO companies are ignored because the bid price tends to be low so that with the presence or absence of risk, the initial return is almost certain to be realized by investors. This statement is supported by Jogiyanto (2017) who released data in the range of 2000-2014 the initial return of IPO shares was always positive. Murugesu \& Santhapparaj (2010) found that the disclosure of risk in a prospectus can reflect the offering price and initial return of IPO shares. According to signal theory, companies that conduct risk disclosures can affect investor perceptions both negatively and positively. If risk information is perceived positively, it will reduce the initial return. Conversely, if risk information is perceived negatively, it will increase the initial return. Then, if risk information is not perceived as providing relevant information, then an insignificant influence between risk and initial return occurs.Based on previous analysis, the hypotheses proposed in this study are: $\mathrm{H}_{1}$ : There is significant association between quantitative risk disclosure and the initial return

$\mathrm{H}_{2}$ : There is significant association between qualitative risk disclosure and the initial return

\section{RESEARCH METHOD}

The population in this study is companies that conduct initial public offering (IPO) in Indonesia in the range of 1 January 2017-31 December 2018. This period was chosen based on the fact that 2017 and 2018 are the years with the most number of IPO companies in the last 20 years on the Indonesia Stock Exchange. There is an increase of more than 200 percent of the number of IPO issuers compared to the previous year which made 2017 "a new start" in the IPO phenomenon in Indonesia. The number of companies conducting IPOs in the study period was 94 companies (37 companies in 2017; 57 companies in 2018). The purposive sampling method is applied to eliminate characteristics that are not in accordance with variable criteria such as the date of the prospectus which is not one full year and the incomplete prospectus report. After going through sample selection, there are 62 companies who become the final sample of this study.

The dependent variable in this study is stock returns on the first day of trading on the secondary market, better known as the initial return. The initial return is measured by the difference in the closing price of shares on the first day with the offer price divided by the IPO offer price. Positive percentage values indicate that the offer price is too cheap which is commonly referred to as the underpricing phenomenon. On the other hand, a negative value indicates that the offer price of shares is too expensive (overpriced). This measurement is commonly used in various studies such as (Brobert, 2016); (Murugesu \& Santhapparaj, 2010); (Yan, et al., 2018); and (Wasiuzzaman et al., 2018).

The independent variable in this study is risk disclosure. Risk disclosures are classified into two types; qualitative risk disclosures and quantitative risk disclosures. Qualitative risk is the risk in the prospectus presented textually in the form of a collection of paragraphs and descriptions. Meanwhile, quantitative risk disclosure is measured using financial measures which in this case are adapted from ratios / inputs derived from research Murugesu and Santhapparaj (2010). There are 5 proxies used as quantitative risk measures; liquidity, earnings variability, sales growth, company age, and audit quality.

Qualitative risk disclosure is proxied into 3 variables; operational risk (OPR), general risk (GEN), and investment risk (INV). OPR, GEN, and INV variables are calculated based on the number of risk statements in the prospectus. This data is presented in a section of the prospectus with the heading "Risk Factor". Quantitative risk disclosure consists of 5 proxies; liquidity (LIQ), earnings variability (VAR), sales growth (GRO), company age (AGE), and auditor reputation (REP). LIQ is measured using the current ratio formula, that is, current assets divided by short-term debt. GRO is measured by the increase / decrease in sales of $\mathrm{t}-1$ IPO divided by the value of t-2 IPO sales. VAR is calculated using the standard deviation of the company's net income 3 years before the IPO. The age of the company is based on the year of the deed of establishment of the company which can be seen in the Notes to the Financial Statements. Finally, auditor reputation is a dummy variable ( 1 if non-big four and 0 if big four). 
This study uses the ordinary least square (OLS) regression method to test the research hypothesis. The following is a regression model that will be applied to OLS regression analysis:
The third model is a function of significant variables in models 1 and 2 . This model is raised by setting aside insignificant variables and combining significant variables into one model. Model 1 is a

$$
\begin{aligned}
& I R_{i}=\alpha_{0}+\beta_{1} O P R_{i, j}+\beta_{2} G E N_{i, j}+\beta_{3} I N V_{i, j}+\varepsilon_{i} \\
& I R_{i}=\alpha_{0}+\beta_{1} L I Q_{i, j}+\beta_{2} V A R_{i, j}+\beta_{3} G R O_{i, j}+\beta_{4} A G E_{i, j}+\beta_{5} R E P_{i, j}+\varepsilon_{i} \\
& I R_{i}=f(\text { any significant variable }(s) \text { from model (1) and (2) ) }
\end{aligned}
$$

model that tests the ability of qualitative risk on stock prices. Meanwhile, model 2 is used for quantitative risk. Models 1 and 2 are tested separately in order to see the direct effect of risk disclosure in the prospectus without presenting a reciprocal effect between qualitative and quantitative risk disclosures. In the third model the variables are combined based on significance and tested together to directly compare the effects of qualitative and quantitative risk disclosures. The third model shows which risks have the greatest effect (indicated by the value â) on the initial return of an IPO company.

\section{RESULTS AND DISCUSSION}

The descriptive statistics for a sample of IPO companies on the Indonesia Stock Exchange for the 2017-2018 period are presented in Table 1. Like the previous literature, the phenomenon of underpricing also occurs in this study. The average IPO company produces a return of $47 \%$ on the first day of shares traded on the capital market. The offering price of IPO companies tends to be low which in this study is connected due to the inherent risk in the company. The highest value of the company's return reaches 70 percent with the lowest value at a loss of 35 percent.

Qualitative risk is proxied by 3 variables, OPR, GEN, and INV. The average company revealed more information about the company's operating risks with an average of 9.35 . This amount is even greater than the general risk statement and the investment risk is added up. This means the external conditions of companies in Indonesia do not have excessive effects compared to the internal and operational conditions of companies. Some companies also do not disclose general risks and investments (this can be caused by the impact of the risks which are not material and significant). In general, the company presents a specific section for disclosure of risk factors in the prospectus as regulated in applicable regulations.

Quantitative risk variables present various figures. IPO company liquidity tends to vary with a

Table 1. Descriptive Statistics of Research Samples $(\mathrm{N}=62)$

\begin{tabular}{llrrrr}
\hline Variables & Abr. & Minimum & Maximum & Standard \\
Initial Return & IR & -0.35 & 0.70 & 0.47 & 0.27 \\
Operating Risk & OPR & 3 & 30 & 9.35 & 5.04 \\
General Risk & GEN & 0 & 11 & 4.37 & 3.42 \\
Investment Risk & INV & 0 & 14 & 2.22 & 1.83 \\
Liquidity & LIQ & 0.08 & 14.41 & 0.28 & 2.83 \\
Sales Growth & GRO & -0.77 & 2.65 & 35.237 & 0.50 \\
Earnings Var. & VAR & 22 & 426.811 & 16.03 & 69.213 \\
Company Age & AGE & 2.00 & 59.00 & 1 & 0.87
\end{tabular}

Notes: IR is the initial return measured from the difference in closing price of shares on the first day with the offer price divided by the IPO offer price. OPR. GEN. and INV are calculated based on the number of risk statements contained in the prospectus. This data is presented in a special section of the prospectus with the general title "Risk Factors". LIQ is measured using the formula of current assets divided by short-term debt. GRO is measured by the increase / decrease in sales of t-1 IPO divided by the value of t-2 IPO sales. VAR is calculated using the standard deviation of the company's net income 3 years before the IPO. The age of the company is based on the year of the deed of incorporation which can be seen in the Notes to the Financial Statements. Finally. auditor reputation is a dummy variable (1 if non-Big Four and 0 if Big Four).

Source: Data Processed, 2019 
standard deviation value that is greater than the average value. The average liquidity is 2.22 , which indicates that on average the company has no problem paying its short-term obligations. Sales growth has an average of $28 \%$, indicating that IPO companies are quite optimistic about entering the Indonesian capital market with a positive growth value. Earnings variability is quite varied marked by the greater value of the standard deviation compared to the average value. This is because the company consists of various sectors and sizes that make the ability to generate profits vary. Moreover, in this study due to the limited number of samples, samples cannot be categorized by specific sectors. The age of companies conducting IPOs during 2017-2018 has an average of 16 years, which indicates that the company is in the development/expansion phase. Finally, IPO companies use more big four non-affiliated auditors. Only 13 percent of the sample companies that use auditors are affiliated with the big four.

The correlation coefficient between the dependent and independent variables is quite low, with the highest value of -0.630 between REP and VAR with a significance below 1 percent. There are 5 independent variables that have a significant correlation with IR; GEN, INV, VAR, AGE, and REP with a significance level of 1 percent and 5 percent. Among the independent variables, OPR has a significant correlation with GEN and INV. This confirms that the disclosure of qualitative risks takes into account each other's quantification of each type of risk supported by the relationship of OPR, GEN, and INV variables that are positively correlated. Qualitative risk disclosure is also related to quantitative risk. OPR has a negative correlation with REP, GEN has a positive correlation with AGE, and INV has a positive correlation with VAR and a negative correlation with REP. Between quantitative risks, there are only two significant correlations, namely between GRO with AGE and REP with VAR. Liquidity has no correlation with other variables. Overall, the correlation between the independent variables did not indicate any indication of multicollinearity and the results of the VIF test also showed that the eight independent variables had values below 10 that represented no symptoms of multicollinearity.

The results of multiple linear regression testing in all three models are presented in Table 3. All

Table 2. Correlation Among Variables

\begin{tabular}{|c|c|c|c|c|c|c|c|c|c|c|}
\hline & IR & OPR & GEN & INV & LIQ & GRO & VAR & AGE & REP & VIF \\
\hline IR & 1 & & & & & & & & & \\
\hline OPR & -320 & 1 & & & & & & & & 2.075 \\
\hline GEN & $-.312^{* *}$ & $.332^{* * *}$ & 1 & & & & & & & 1.344 \\
\hline INV & $-.379^{* * *}$ & $.606^{* * *}$ & $.262^{* *}$ & 1 & & & & & & 1.807 \\
\hline LIQ & .101 & -.180 & .019 & -.031 & 1 & & & & & 1.089 \\
\hline GRO & .133 & -.157 & -.010 & -.140 & .040 & 1 & & & & 1.115 \\
\hline VAR & $-.252^{* *}$ & .191 & .209 & $.292^{* *}$ & .133 & -.113 & 1 & & & 1.908 \\
\hline AGE & $-.268^{* *}$ & .030 & $.308^{* *}$ & .185 & .022 & $-.278^{* *}$ & .047 & 1 & & 1.312 \\
\hline REP & $.410^{* * * *}$ & $-.492^{* * *}$ & -.117 & $-.467^{* * *}$ & .072 & .140 & $-.630^{* * *}$ & .075 & 1 & 2.406 \\
\hline
\end{tabular}

models have a good Goodness of Fit with a Prob $>$ F value significant at the $1 \%$ level. Model 1 shows an indication of the relationship between qualitative risk disclosure and stock returns. Similar results are also shown by model 2 where two variables show significance at the $1 \%$ level of initial IPO company returns. In the first model, the relationship of each variable is found to be entirely negative. This proves that risk disclosure adversely affects market returns. Investors perceive risk information negatively thereby minimizing the effect of underpricing. The strength of the model is quite weak because it only has a small R-Squared value. Qualitative risk disclosure is only able to explain the return variability of $15.5 \%$. Based on the information above, the first hypothesis is accepted because there is at least one significant independent variable in hypothesis testing, with an F-value indicating that the overall model is valid. In the second model, qualitative risk disclosure also has an association with the variability of the company's initial return. The strength of the second model is stronger than the first model with an R-Squared value of $19.9 \%$. The model is valid enough with the significance of the $\mathrm{F}$ test below $1 \%$. Only two independent variables have a significant effect on stock returns, namely AGE and REP. Thus, the 
second hypothesis is also accepted that quantitative risk disclosure has a significant effect on the initial return on IPO shares.

The third model uses four variables consisting of two quantitative disclosure variables (REP and AGE) and two qualitative disclosure variables (GEN and INV). The selection of the four variables is based on the significance values obtained from the two models that have been tested previously. The results of multiple linear regression tests show that model 3 shows that the role of quantitative information is superior in explaining stock returns. Two qualitative risk variables do not show sufficient significance to explain stock returns after being interacted with quantitative risk. The coefficient of determination of model 3 shows an increase compared to the previous two models that is equal to $25.4 \%$. Although still low, the selection of significant variables in the previous two tests was able to increase the explanatory ability of the dependent variable variability to $25.4 \%$. Model 3 is also valid because the Prob $>F$ value is significant at the $1 \%$ level which indicates that the model has good goodness of fit. The existence of testing in model 3 also shows that risk disclosure has an effect on the initial return of IPO company shares.

Table 3. Regression Results

\begin{tabular}{llll}
\hline \multirow{2}{*}{ Variables } & \multicolumn{3}{c}{ Beta value } \\
\cline { 2 - 4 } & Model 1 & Model 2 & Model 3 \\
\hline Constant & $0,749^{*}$ & $0,246^{* * *}$ & $0,455^{* *}$ \\
OPR & $-0,005$ & - & - \\
GEN & $-0,023^{*}$ & - & $-0,018$ \\
INV & $-0,040^{*}$ & - & $-0,020$ \\
LIQ & - & 0,007 & - \\
GRO & - & $-0,008$ & - \\
VAR & - & 0,000 & - \\
AGE & - & $-0,007^{* *}$ & $-0,05^{*}$ \\
REP & - & $0,364^{* * *}$ & $0,276^{* * *}$ \\
\hline R-Squared & 0,155 & 0,199 & 0,254 \\
Prob $>$ F & 0,005 & 0,003 & 0,000 \\
\hline
\end{tabular}

Source: Data Processed, 2019

The results of this study support several prior studies (Dicle \& Abdou, 2007; Kim \& Yasuda, 2017; Murugesu \& Santhapparaj, 2010). Risk has information value in the process of valuating IPO shares the first day. General and investment risk information has a negative effect on the initial return, which indicates that the more companies submit this information, the less the initial expected return. General information contains information related to aspects of macro conditions in which companies operate. This type of risk is difficult for the company to control because this risk comes from the company's external. Companies that have many external risks indicate that the company is not able to adjust and anticipate market conditions so that the company's operations depend on aspects outside the company's control (Wang, et al., 2018)

Dicle and Abdou (2007) concluded that trader (investor) behave selectively in assessing risk. In fact, risk can be seen as an opportunity if reviewed further. In contrast to the results of the study, the results of this study indicate that risk cannot be transformed into a potential thing. All types of risk are perceived as negative. Investment risk even has a beta value that is greater than general risk. That is, investment risk provides a greater impact in reducing the company's initial return. This can be explained as a new company, IPO company shares are at risk, the source of information only comes from the company's fundamental information not the technical information (Yan et al., 2018). This result is different from the Wasiuzzaman et al. (2018) research findings which in the research model found investment risk as the only type of risk that significantly affected company returns. The different results of this study with previous studies indicate that the culture of risk disclosure in Indonesia cannot be positively perceived by investors in Indonesia. The risk of being perceived negatively can be due to limited company IPO information. The limited information makes the company's shares risk unstable (fluctuating) so that investors who want to make long-term investments take a relatively large risk compared to shares of companies that have been registered. More and more companies disclose risks related to company stock, creating uncertainty that is responded negatively by investors.

Based on the discussion in the previous paragraph, it can be concluded that risk can reduce the impact of the underpricing phenomenon in Indonesia. Stock valuation expectedly can not be cheaper if the company discloses more risk 
information. On the other hand, the findings of this study can be used by IPO company to reduce disclosure of less material risk in prospectus reports to increase the price of initial shares.

Based on quantitative aspect, only the auditor's reputation and company's age influence the initial return. Both the age and the auditor's reputation provide contradictory results when compared with the initial hypothesis. These results are quite odd when compared to studies replicated by Murugesu \& Santhapparaj (2010). They found age and reputation had a significant effect but in a positive direction. Based on the results of this research, the age and reputation of the auditor have a negative effect on the initial return. This opposite findings can be explained in the context of Indonesia, a company that has long been established and uses auditors affiliated with the big-four auditor actually provides a negative response to investors. This may be caused by long existed-company does/should not experience financial problems. Anewly established company is considered normal if it conducts an IPO on the capital market. Auditor reputation has a negative tendency which is proven empirically that public accounting firm with a non-big four predicate can provide positive sentiment for investors. This finding confirms the possibility that investors do not understand the audit quality benefits of the big four public accounting firm. In addition, the use of the big four auditor might be considered to only add costs to the company which have an impact on negative perceptions by investors. This is also supported by the results of research by Shabrina (2013).

\section{CONCLUSION}

This research proves that risk disclosure has an influence on company's initial return. Risk becomes a negative factor which in several aspects influences the determination of the IPO's initial share price. Risk is a general consideration in an investment. In the context of investing in IPO companies, there are two types of risks that need to be considered; qualitative risk and quantitative risk. The high growth rate of IPO companies in Indonesia in the 2017-2018 range shows the potential economic condition in Indonesia. Risk factor, even though it is a partial consideration, can influence the determination of the initial stock price in the capital market. The low share price of an IPO company is also influenced by the company's risk disclosure. By using textual and numerical proxies, this study found that prospectus information has relevance to the first day's stock price on the capital market.
The limitations are this study only use 2-year period so the samples collected lack the generalization power. This study also did not compare the impact of qualitative and quantitative information. This research can continue to be explored in the future by taking into account the following aspects: future research can use a text codification system on risk disclosure and categorize effects based on the type of industry which cannot be carried out in this study due to the limitations of the sample. Finally, next study is recommended to conduct a test to measure the superiority between qualitative risk and quantitative risk.

This research also has a new contribution to the topic of risk disclosure by analyzing risks in a dual perspective. The use of qualitative and quantitative forms of risk can be used in further research. This research proves that risk disclosure influences decision making. The regulation regarding prospectus information disclosure, especially in the risk factor section needs to be evaluated continuously considering the uniformity of disclosures by companies is still not quite commensurate in terms of broad presentation. In addition, the findings of this study can also provide recommendations for investors to recognize risk again not only as a sentiment/stigma, but also as an information disclosure by the company as a manifestation of accountability which at a point needs to be appreciated. Further study of this problem will provide more significant results for the development of the topic of underpricing and financial statement disclosure.

\section{REFERENCES}

Ameer, R., \& Othman, R. (2009). Market risk disclosure: evidence from Malaysian listed firms. Journal of Financial Regulation and Compliance, 17(1), 57-69. doi:10.1108/ 13581980910934045

Auliya, R., \& Januarti, I. (2015). Pengaruh Mekanisme Corporate Governance Terhadap Tingkat Underpricing IPO. Diponegoro Journal of Accounting, 4(4).

Brobert, G. (2016). The global REIT market: initialday performance of IPOs. Journal of European Real Estate Research, 9(3), 231-249. doi:10.1108/JERER-03-2016-0015

Chen, C., \& Wang, X. (2016). The impact of the reputation of underwriter and sponsoring representative on IPO underwriting fees. China Finance Review International, 6(4), 342-366. doi:10.1108/CFRI-07-2015-0109 
Chhabra, S., Kiran, R., \& Sah, A. N. (2017). Information asymmetry leads to underpricing: validation through SEM for Indian IPOs. Program, 51(2), 116-131. doi:10.1108/PROG01-2016-0009

Colak, G. (2012). IPO characteristics of index firms. Managerial Finance, 38(12), 1134-1159. doi:10.1108/03074351211271265

Cordazzo, M., Papa, M., \& Rossi, P. (2017). The interaction between mandatory and voluntary risk disclosure: a comparative study. Managerial Auditing Journal, 32(7), 682-714. doi:10.1108/MAJ-01-2016-1308

Craig, R., Lima Rodrigues, L., \& Oliveira, J. (2011). Risk related disclosures by non finance companies: Portuguese practices and disclosure characteristics. Managerial Auditing Journal, 26(9), 817-839. doi:10.1108/02686901111171466

Dicle, M. F., \& Abdou, K. (2007). Do risk factors matter in the IPO valuation? Journal of Financial Regulation and Compliance, 15(1), 63-89. doi:10.1108/13581980710726796

Dimovski, B. (2016). Differences in underpricing of A-REIT IPOs and Australian property company IPOs. Journal of Property Investment \& Finance, 34(2), 107-115. doi:10.1108/JPIF-062015-0041

Gomez-Bezares, F., Alcaniz, L., \& Ugarte, J. V. (2015). Firm characteristics and intellectual capital disclosure in IPO prospectuses. Academia Revista Latinoamericana de Administración, 28(4), 461-483. doi:10.1108/ ARLA-09-2014-0134

Gunawan, R., \& Darmadi, S. (2013). Underpricing, board structure, and ownership: An empirical examination of Indonesian IPO firms. Managerial Finance, 39(2), 181-200. doi:10.1108/03074351311294016

Jain, B. A. (2005). The Association Between Audit Quality and Post IPO Performance: A Survival Analysis Approach. Review of Accounting and Finance, 4(4), 50-75. doi:10.1108/eb043437

Jogiyanto. (2017). Teori Portofolio dan Analisis Investasi (11 ed.): BPFE.

Kim, H., \& Yasuda, Y. (2017). Business risk disclosure and firm risk: Evidence from Japan. Research in International Business and Finance, 45, 413-426.
Murugesu, J., \& Santhapparaj, A. S. (2010). Impact of risk disclosure in the prospectus on valuation and initial returns of initial public offerings in Malaysia. IUP Journal of Applied Finance, 16(6), 30-53.

Ozdemir, O., \& Kizildag, M. (2017). Does franchising matter on IPO performance?: An examination of underpricing and post-IPO performance. International Journal of Contemporary Hospitality Management, 29(10), 2535-2555. doi:10.1108/IJCHM-11-2015-0662

Rock, K. (1986). Why new issues are underpriced. Journal of Financial Economics, 15(1-2), 187-212.

Shabrina, K. K. N. (2013). Pengaruh Kualitas Audit Terhadap Kemampuan Investor Memprediksi Laba di Masa Depan. Diponegoro Journal of Accounting, 2(3), 1-12.

Shukor, Z.A., Mohamed, Z. M., Ahmad,A., \& Abdullah, M. (2015). Risk management disclosure: A study on the effect of voluntary risk management disclosure toward firm value. Journal of Applied Accounting Research, 16(3), 400-432. doi:10.1108/JAAR-10-2014-0106

Wang, Y., Li, G, Li, J., \& Zhu, X. (2018). Comprehensive identification of operational risk factors based on textual risk disclosures. Procedia Computer Science, 139, 136-143. doi:https://doi.org/ 10.1016/j.procs.2018.10.229

Wasiuzzaman, S., Yong, F. L. K., Sundarasen, S. D. D., Othman, N. S., \& Wasiuzzaman, S. (2018). Impact of disclosure of risk factors on the initial returns of initial public offerings (IPOs). Accounting Research Journal, 31(1), 46-62. doi:10.1108/ARJ-09-2016-0122

Xu, Z.-J., Wang, L., \& Long, J. (2017). The impact of director's heterogeneity on IPO underpricing. Chinese Management Studies, 11(2), 230-247. doi:10.1108/CMS-05-2016-0095

Yan, Y., Xiong, X., Meng, J. G., \& Zou, G. (2018). Uncertainty and IPO initial returns: Evidence from the Tone Analysis of China's IPO Prospectuses. Pacific-Basin Finance Journal. doi:https://doi.org/10.1016/j.pacfin.2018.10.004 